\title{
Aspek Laboratorium Gagal Ginjal Kronik
}

\author{
Febtarini Rahmawati \\ Bagian Patologi Klinik Fakultas Kedokteran Universitas Wijaya Kusuma Surabaya \\ e-mail: febtapatklin@gmail.com
}

\begin{abstract}
Abstrak
Penyakit ginjal kronik adalah gangguan fungsi atau struktur ginjal yang berlangsung selama lebih dari tiga bulan, disertai penurunan laju filtrasi glomerulus. Pemantauan penurunan fungsi ginjal dilakukan dengan cara pengukuran laju filtrasi glomerulus, menentukan kadar urea darah, kreatinin, klirens kreatinin, elektrolit, asam urat, analisis gas darah dan fungsi tubulus. Metode lama untuk mengukur laju filtrasi glomerulus menggunakan klirens inulin, namun tidak praktis. Selanjutnya dikembangkan pengukuran laju filtrasi glomerular berdasarkan kreatinin. Pengukuran urea, kreatinin dan asam urat darah saat ini menggunakan metode enzimatik spektrofotometri, sedangkan pemeriksaan elektrolit dengan metode elektrode ion selektif (ISE). Analisis gas darah menetapkan $\mathrm{pH}$, $\mathrm{PCO}_{2}, \mathrm{PO}_{2}, \mathrm{HCO}_{3}{ }^{\circ}, \mathrm{CO}_{2}$ total, base excess dan $\mathrm{SO}_{2}$. Pemeriksaan protein urine dan sedimen urine membantu menegakkan diagnosis penyakit ginjal kronik.
\end{abstract}

Kata Kunci: penyakit ginjal kronik, laju filtrasi ginjal, kreatinin

\section{Laboratory Aspect Of Chronic Kidney Disease}

\begin{abstract}
Chronic renal disease is a disorder of renal function or structure that lasts for more than three months, accompanied by a decrease in glomerular filtration rate. Decreasing of renal function monitoring is performed by measuring glomerular filtration rate, determining blood urea, creatinine, creatinine clearance, electrolytes, uric acid, blood gas analysis and tubular function. The Recent method for measuring glomerular filtration rate using inulin clearance, however, is not efficient. Further measurements of creatinine glomerular filtration rate were developed. Measurements of urea, creatinine and uric acid are currently using enzymatic methods of spectrophotometry, while electrolyte examination by selective ion electrode method. Blood gas analysis determined $\mathrm{pH}, \mathrm{PCO}_{2}, \mathrm{PO}^{2}, \mathrm{HCO}_{3}{ }^{\circ}, \mathrm{CO}_{2}$ total, base excess and $\mathrm{SO}_{2}$. Examination of urine protein and urine sediments helps establish a diagnosis of chronic kidney disease
\end{abstract}

Keywords: chronic kidney disease, Glomeruler Filtrat Rate, creatinine

\section{PENDAHULUAN}

Sepasang ginjal terletak retroperitoneal di kiri dan kanan vertebra, di bagian dorsal abdomen setinggi torakal 12-13. Ukuran ginjal $11-12 \mathrm{~cm} \times 5-7,5 \mathrm{~cm} \times 2,5-3 \mathrm{~cm}$, dengan berat 115-170 gram pada orang dewasa. Satuan unit fungsional terkecil ginjal adalah nefron, setiap ginjal terdiri dari 1-1,5 juta nefron. Nefron terdiri dari glomerulus, tubulus proksimalis, lengkung Henle, tubulus distalis dan tubulus koligentes. Fungsi nefron adalah membersihkan darah dari zat yang tidak dikehendaki oleh tubuh, antara lain produk akhir metabolisme seperti kreatinin, ureum dan asam urat. Proses yang terjadi di nefron adalah filtrasi di glomerulus, reabsorbsi dan sekresi di tubulus(1,2).

Penyakit ginjal kronik merupakan perkembangan penyakit ginjal yang progresif yang berlangsung lebih dari tiga bulan. Ginjal kehilangan kemampuannya untuk mempertahankan volume dan keseimbangan komposisi cairan tubuh. Penyakit ginjal kronik terjadi setelah berbagai macam penyakit 
merusak massa nefron ginjal. Pada awalnya, beberapa penyakit ginjal menyerang glomerulus dan tubulus ginjal, selanjutnya mengganggu perfusi darah pada parenkim ginjal karena defisiensi jumlah nefron yang berfungsi. Perjalanan klinis penyakit ginjal kronis pada mulanya terjadi penurunan fungsi ginjal. Selama stadium ini kreatinin serum dan kadar urea serum masih normal dan pasien asimtomatik. Perkembangan selanjutnya adalah insufisiensi ginjal, bila lebih dari $75 \%$ jaringan yang berfungsi telah rusak dan GFR $25 \%$ dari normal. Pada tahap ini kadar urea serum meningkat diatas batas normal. Stadium akhir gagal ginjal kronik disebut penyakit ginjal stadium akhir (ESRD/ End stage renal disease) atau uremia. ESRD terjadi bila lebih dari $90 \%$ massa nefron telah hancur atau sekitar 20.000 nefron yang masih utuh. Nilai GFR hanya 10\% dari normal, kreatinin serum dan urea serum meningkat sebagai respons terhadap laju filtrasi glomerulus yang sedikit menurun $(1,2)$.

Penyakit ginjal kronik merupakan keadaan klinis kerusakan ginjal yang progresif dan irreversible karena berbagai penyebab. (2) Penyebab gagal ginjal kronik adalah:

1. Penyakit infeksi tubulointerstitial:

- Pielonefritis kronik

- Refluks nefropati

2. Penyakit peradangan: Glomerulonefritis

3. Penyakit vaskular hipertensi: Nefrosklerosis (benigna, maligna)

4. Gangguan jaringan ikat:

- Lupus eritematosus sistemik

- Poliarteritis nodosa

- Sklerosis sistemik progresif

5. Gangguan kongenital dan herediter:

- Penyakit ginjal polikistik

- Asidosis tubulus ginjal

6. Penyakit metabolik: -Diabetes mellitus

- Gout

- Hiperparatiroid

- Amiloidosis

7. Nefropati toksik:

- Obat analgesik

- Nefropati timah

8. Nefropati obstruksi:

- Traktus urinarius bagian atas: batu, neoplasma, fibrosis, retroperitoneal

- Traktus urinarius bagian bawah: hipertropi prostat, striktura uretra, Anomali kongenital

- Pemantauan pemeriksaan laboratorium penyakit ginjal kronis membantu diagnosis kerusakan ginjal pada pasien, manajemen pengobatan dan menentukan derajat kerusakan fungsi ginjal, yakni mengevaluasi kreatinin, urea serum, bersihan ginjal, pemeriksaan urine, elektrolit dan cairan tubuh, keseimbangan asam basa darah. Tes laboratorium dilakukan juga untuk mengevaluasi penyakit-penyakit lain yang seringkali menyertai penyakit ginjal kronis, misalnya diabetes, osteoporosis, penyakit jantung dan pembuluh darah. Stadium yang lebih dini dari penyakit ginjal kronik bisa diketahui melalui pemeriksaan laboratorium rutin(3).

Diagnosis penyakit ginjal kronik ditegakkan dengan melihat beberapa gejala berikut $(4,5)$ :

1. Penurunan GFR minimal tiga sampai 6 bulan

2. Azotemia lebih dari tiga bulan

3. Adanya gejala uremia

4. Gejala dan tanda renal osteodystrophy

5. Ginjal mengecil bilateral

6. Didapatkan broad casts pada sedimen urine

\section{PEMANTAUAN PENURUNAN FUNGSI GINJAL}

\section{Laju Filtrasi Glomerulus.}

Laju filtrasi glomerulus digunakan sebagai ukuran untuk mengetahui besarnya kerusakan ginjal karena filtrasi glomerulus merupakan tahap awal dari fungsi nefron. Besarnya laju filtrasi glomerulus sama dengan klirens suatu bahan yang difiltrasi secara bebas oleh glomerulus, tidak direabsorbsi dan tidak disekresi oleh tubulus ginjal. Klirens yaitu volume darah atau plasma yang dibersihkan dari bahan tertentu oleh ginjal dalam satu satuan waktu. Bahan penanda filtrasi adalah bahan endogen dan bahan eksogen. Bahan endogen berat molekul kecil seperti Kreatinin, Cystatin-c, B-2 mikroglobulin, $\alpha-1$ mikrogobulin dan retinol binding protein. Bahan penanda filtrasi eksogen yakni inulin, PAH/ Para amino hipurat, iohexol, DTPA, 99m Tc-diethylene triamine penta acetic acid, 51-Cr-EDTA dan 125 I-iothalamate. (6)

GFR $\varangle 0 \mathrm{ml} /$ menit/1,73 $\mathrm{m}^{2} \geq 3$ bulan diklasifikasikan sebagai penyakit ginjal kronis. Ginjal telah kehilangan fungsinya $\geq 50 \%$. Derajat penurunan laju filtrasi glomerulus pada penyakit ginjal kronik, dibagi menjadi 5 stadium (6): 
1. Stadium 1: Kerusakan ginjal dengan GFR $\geq$ $90 \mathrm{ml} / \mathrm{menit} / 1,73 \mathrm{~m}^{2}$

2. Stadium 2: Kerusakan ginjal dengan penurunan GFR ringan $60-89$ $\mathrm{ml} / \mathrm{menit} / 1,73 \mathrm{~m}^{2}$

3. Stadium 3: Penurunan GFR sedang 30 - 59 $\mathrm{ml} /$ menit/ $1,73 \mathrm{~m}^{2}$

4. Stadium 4: Penurunan GFR berat $15-29$ $\mathrm{ml} / \mathrm{menit} / 1,73 \mathrm{~m}^{2}$

5. Stadium 5: Gagal ginjal, GFR $<15$ $\mathrm{ml} / \mathrm{menit} / 1,73 \mathrm{~m}^{2}$ atau sudah menjalani dialisis

\section{Kreatinin}

Kreatinin merupakan zat nonprotein nitrogen sebagai hasil metabolisme kreatin otot, zat endogen yang difiltrasi bebas, tidak mengalami reabsorbsi ditubulus ginjal, tetapi sejumlah kecil kreatinin disekresi oleh sel tubulus ginjal. Kadarnya di plasma relatif konstan dan klirensnya dapat diukur sebagai indikator laju filtrasi glomerulus. Produksi kreatinin berdasarkan masa otot, usia, jenis kelamin dan berat badan. Ekskresi harian dipengaruhi diet kreatinin dari daging. Peningkatan kadar kreatinin berhubungan dengan fungsi ginjal terutama glomerulus. Kadar kreatinin darah memiliki variasi diurnal karena asupan makanan, sebaiknya darah diambil dalam keadaan puasa. Meski demikian penilaian fungsi ginjal berdasarkan laju filtrasi glomerulus masih banyak yang menggunakan kreatinin karena biaya yang lebih murah, mudah dilakukan dan klirens kreatinin adalah parameter yang baik untuk menilai fungsi ginjal $(7,8)$.

Metode analisis yang digunakan untuk mengukur kreatinin adalah metode kimia berdasarkan reaksi Jaffe, metode enzimatik dan High performance liquid chromatography (HPLC). Nilai kreatinin serum normal: 0,6 - 1,3 $\mathrm{mg} / \mathrm{dL}$. Kreatinin serum $>1,5 \mathrm{mg} / \mathrm{dL}$ menunjukkan telah adanya gangguan fungsi ginjal.

Beberapa rumus yang digunakan untuk memperkirakan laju filtrasi glomerulus melalui kadar kreatinin darah adalah $(9,10,11)$

\footnotetext{
Rumus Cockcroft - Gault $=$ GFR $=\underline{(140-\text { usia }) \text { X berat badan X 1,73 }}$ 72 X Pcr XA

$\mathrm{Pcr}=$ kadar kreatinin darah $(\mathrm{mg} / \mathrm{dL})$

$A=$ luas permukaan tubuh $\left(\mathrm{m}^{2}\right)$

Untuk wanita rumus tersebut dikalikan dengan 0,85 yang merupakan koreksi $15 \%$ dari pria.
}

\section{Rumus MDRD (Modification of Diet in Renal Disease):}

GFR (mL / mnt / 1,73 $\left.\mathrm{m}^{2}\right)=186 \mathrm{X}$ (kreatinin serum) $)^{-1,154} \mathrm{X}$ (umur) ${ }^{-0,203} \mathrm{X}(0,742) \mathrm{X}$ $(1,210)$

\section{Bersihan suatu zat / Klirens}

Klirens dari suatu zat adalah volume dari plasma yang dibersihkan dari zat tersebut dalam satuan waktu. Zat yang difiltrasi kemudian tidak direabsorbsi maupun disekresi adalah inulin, nilai bersihannya sesuai dengan laju filtrasi glomerulus. Pemeriksaan laju filtrasi glomerulus dengan menggunakan zat inulin kurang praktis sehingga tidak dilakukan untuk pemeriksaan rutin(11,12).

Klirens kreatinin merupakan cara yang banyak digunakan untuk mengukur GFR. Klirens kreatinin secara konvensional memerlukan pengumpulan urine $24 \mathrm{jam}$. Hal ini menjadi kendala bila nilai GFR perlu segera diketahui, juga bila ada berbeda pemahaman mengenai pengumpulan urine 24 jam yang benar. Untuk menghindari kesalahan penilaian karena pengumpulan urine, digunakan rumus bersihan tanpa pengukuran kadar kreatinin urine yakni rumus Cockcroft-Gault $(13,14)$.

Rumus Klirens kreatinin $(\mathrm{mL} / \mathrm{menit})=$ Kreatinin urine $(\mathrm{mg} / \mathrm{dL}) \mathrm{X}$ volume urine $(\mathrm{ml} /$ menit) X 1,73 Kreatinin serum $(\mathrm{mg} / \mathrm{dL}) \times A\left(\mathrm{~m}^{2}\right)$

$A=$ luas permukaan tubuh dengan menggunakan nomogram Du Bois.Klirens kreatinin normal $100-180 \mathrm{ml} /$ menit. Nilai dibawah $90 \mathrm{ml} /$ menit (dikoreksi terhadap luas permukaan tubuh) menunjukkan penurunan laju filtrasi glomerulus.

Zat yang difiltrasi kemudian direabsorbsi dan dikatabolisir ditubulus dan secara tidak langsung menggambarkan GFR adalah Cystatin $\mathrm{C}$ (CysC).

\section{Cystatin-C (Cys C)}

Cystatin- $\mathrm{C}$ suatu proteinase cysteine, termasuk gen cystatin non glycosylated tipe II terdiri dari 122 asam amino dengan berat molekul 13,3 KD dengan isoelectric point 9,0 (bermuatan positif saat berada di glomerulus), hal ini menyebabkan Cystatin- $C$ mudah melewati membran basalis yang bermuatan negatif. Cystatin- $\mathrm{C}$ diproduksi oleh sel berinti dengan laju relatif tetap dan tidak mengenal variasi diurnal, ditemukan pada semua cairan tubuh, difiltrasi oleh glomerulus dan direabsorbsi ditubulus, mengalami katabolisme 
di tubulus proksimalis, sehingga tidak ada yang kembali ke darah Cystatin-C tidak dipengaruhi usia, luas permukaan tubuh dan jenis kelamin. Dengan demikian, kadar Cystatin- $\mathrm{C}$ dalam darah dapat dipakai untuk menggambarkan GFR. Metode pengukuran kadar Cystatin-C menggunakan radioimmunoassay, enzyme immunoassay, fluorescent immunoassay, particle-enhanced turbidimetric assay, Latex penia particle-enhanced immunonephelometric assay. Kadar Cystatin-C tertinggi pada bayi usia satu hari, kemudian menurun selama empat bulan pertama karena proses pematangan ginjal. Setelah usia satu tahun kadar Cystatin-C menjadi sama dengan usia dewasa(15). Nilai batas yang menunjukkan adanya gangguan GFR $=1,4 \mathrm{mg} / \mathrm{L}$. Dengan cara Latex Penia kadar Cystatin-C darah $=0,37-1,33 \mathrm{mg} / \mathrm{dl}$.

Rumus untuk memperkirakan GFR berdasarkan kadar Cystatin - C serum adalah:

$$
\text { GFR = } \frac{80,35}{\text { Kadar Cystatin - C (mg/dL) }}
$$

\section{UREA}

Senyawa nitrogen non protein dengan konsentrasi tertinggi di dalam darah adalah urea. Urea disintesis didalam hati dari $\mathrm{CO}_{2}$ dan ammonia yang dihasilkan dari proses deaminasi oleh asam amino pada siklus urea. Urea merupakan hasil ekskresi terbesar dari metabolisme protein. Setelah disintesis di dalam hati, urea dibawa ke dalam darah menuju ginjal dan difiltrasi oleh glomerulus. Setelah urea difiltrasi di glomerulus, urea di reabsorbsi di tubulus proksimalis. Reabsorbsi urea sangat dipengaruhi oleh aliran filtrat dalam tubulus, makin lambat aliran makin banyak urea direabsorbsi. Bila dieresis kurang dari $2 \mathrm{ml} /$ menit, nilai klirens urea tidak menggambarkan laju filtrasi glomerulus lagi. Sebagian besar urea di glomerulus di ekskresi ke urine, $>40 \%$ diserap kembali secara difusi pasif dan sebagian kecil $<10 \%$ diekskresikan melalui saluran cerna dan kulit. Konsentrasi urea dalam plasma ditentukan oleh sintesis di hati dan ekskresi melalui urine. Kadar urea darah meningkat pada diet tinggi protein, perdarahan sistem pencernaan, dehidrasi, gangguan fungsi ginjal, adanya bendungan di saluran kemih bagian bawah dan katabolisme protein yang meningkat. Urea darah menurun pada penyakit hati karena amoniak tidak diubah menjadi urea, sehingga peningkatan amoniak mengakibatkan ensefalopati hepatik $(7,8)$.

Urea pernah digunakan untuk pengukuran laju filtrasi glomerulus, namun sekarang tidak digunakan lagi karena kadar urea selama 24 jam dalam darah tidak tetap, dipengaruhi oleh ekskresi ginjal, makanan dan pembentukannya di hati dan nilai klirens urea lebih rendah dari nilai laju filtrasi glomerulus.

Pengukuran urea dilakukan pada filtrat bebas protein dari serum berdasarkan pengukuran jumlah nitrogen, yang terbanyak digunakan adalah metode kinetik yang menggabungkan reaksi urea dengan Lglutamate dehidrogenase (GLDH) dan mengukur tingkat Nikotinamide adenine dinukleotide (NADH tereduksi) pada $340 \mathrm{~nm}(7)$. Reaksi enzimatik dari urea adalah sebagai berikut:

Nilai rujukan urea nitrogen pada serum atau plasma adalah 20 - $30 \mathrm{mg} / \mathrm{dL}$ dan BUN 10 - $20 \mathrm{mg} / \mathrm{dL}$. Peningkatan kadar urea plasma karena retensi nitrogen akibat gangguan fungsi ginjal dikenal sebagai azotemia.

$$
\begin{aligned}
& \text { Urea } \stackrel{\text { urease }}{\longrightarrow} 2 \mathrm{NH}^{+}+\mathrm{HCO}_{3}^{-} \\
& \mathrm{NH}_{4}^{+}+\text {2-oxoglutarate } \stackrel{\mathrm{GLDH}}{\mathrm{NADH}} \underset{\mathrm{NAD}^{+}+\mathrm{H}^{+}}{\longrightarrow} \text { glumate }
\end{aligned}
$$

\section{ELEKTROLIT}

Gangguan keseimbangan elektrolit pada penyakit ginjal kronik adalah hiperkalemia, retensi natrium, hiperphosphatemia, hipokalsemia, hipermagnesemia $(7,8)$.

\section{Kalium}

Kalium sebagian besar disekresi oleh nefron bagian bawah. Pada diet tinggi kalium, akan beradaptasi dengan meningkatkan ekskresi di nefron dan sekresi di usus. Hiperkalemia pada penyakit ginjal kronik karena oliguri, gangguan adaptasi nefron serta kondisi $\mathrm{pH}$ darah yang cenderung asidosis. Hipokalemia jarang terjadi pada penyakit ginjal kronik, namun dapat terjadi pada diet kurang kalium, diare/muntah atau pemakaian obat diuretika. Metode menentukan kadar kalium 
menggunakan elektrode gelas yang hanya bisa ditembus oleh ion $\mathrm{K}^{+}$dan dengan metode fotometer enzimatik. Nilai $\mathrm{K}$ normal $=3,5-5$ $\mathrm{meq} / \mathrm{L}$.

\section{Natrium ( $\mathrm{Na})$}

Pada penyakit ginjal kronik terjadi kegagalan peningkatan ekskresi $\mathrm{NaCl}$ untuk menyesuaikan dengan peningkatan dietnya. Secara fisik, seringkali menyebabkan penumpukan cairan ekstrasesuler berupa hipertensi, edema perifer, kongesti vaskuler, kardiomegali. Stadium lebih lanjut penderita kehilangan $\mathrm{NaCl}$ karena terjadi kerusakan collecting ducts sehingga volume ekstraseluler menurun dan hipotensi. Metode penentuan natrium menggunakan elektrode ion selektif/ISE, fotometri nyala dan fotometri serapan. Nilai normal natrium $=136-146$ meq/L.

\section{Kalsium (Ca)}

Penurunan kadar kalsium total pada penyakit ginjal kronik merangsang sekresi hormon paratiroid dan katabolisme hormon paratiroid terbanyak di ginjal, sehingga terjadi hiperparatiroid sekunder. Penderita penyakit ginjal kronik resisten terhadap hormon paratiroid untuk menormalkan kalsium karena penurunan efek $1,25(\mathrm{OH}) D_{3}$ pada aktifitas hormon paratiroid di tulang. Penentuan klorida menggunakan metode titrasi, elektrode ion selektif metode kolorimetri-amperometrik dan metode fotometri/enzimatik. Nilai normal kalsium total plasma/serum: 8,8 - 10,2 mg/dl.

\section{Fosfat (P)}

Terjadi penurunan ekskresi fosfat pada nefron menyebabkan peningkatan kadar fosfat serum. Nilai normal fosfat plasma/serum normal: $2,5-4,5 \mathrm{mg} / \mathrm{dl}$.

\section{Magnesium}

Peningkatan $\mathrm{Mg}$ serum terjadi saat GFR $<20 \mathrm{ml} /$ menit karena ekskresi menurun dan absorbs di usus tetap normal. Nilai normal magnesium serum: 0,6 - 1,1 mmol/ $\mathrm{L}$.

\section{ASAM URAT}

Asam urat merupakan produk akhir dari metabolisme purin. Asam urat bersifat kurang larut air, oleh enzim urikase / urat oksidase dikatabolisme menjadi alantoin yang larut air. Adenosin dan guanin (purin) berasal dari pemecahan asam nukleat yang diubah menjadi asam urat di dalam hati. Pengangkutan asam urat dalam plasma dari hati menuju ginjal dan diginjal di filtrasi oleh glomerulus. Reabsorbsi asam urat 98 - 100\% terjadi di tubulus proksimalis. Sebagian kecil asam urat disekresi oleh tubulus distal dan $70 \%$ diekskresikan ke urine. Asam urat yang tidak mengalami ekskresi akan masuk ke system pencernaan dipecah oleh enzim dari bakteri. $(7,8)$

Penyakit ginjal kronik menyebabkan kadar asam urat serum meningkat karena adanya gangguan fungsi filtrasi, sekresi ginjal dan ekskresi asam urat melalui urine yang menurun. Metode analisis pemeriksaan asam urat yaitu dengan metode kimia asam fosfotungstat dan metode enzimatik spektrofotometri.

Nilai rujukan asam urat darah dengan metode urikase adalah:

1. Wanita dewasa $=2,6-6 \mathrm{mg} / \mathrm{dl}(0,16-0,36$ $\mathrm{mmol} / \mathrm{L}$ )

2. Pria dewasa $=3,5-7,2 \mathrm{mg} / \mathrm{dl}(0,21-$ $0,43 \mathrm{mmol} / \mathrm{L})$

3. Anak - anak $=2-5,5 \mathrm{mg} / \mathrm{dl}(0,12-0,33$ $\mathrm{mmol} / \mathrm{L}$ )

\section{KESEIM BANGAN ASAM BASA DARAH}

Gangguan keseimbangan asam basa darah pada penyakit ginjal kronik adalah asidosis metabolik yang menyebabkan keluhan mual, lemah, airhunger dan drowsiness. Asidosis metabolik dapat disebabkan oleh karena ekskresi asam yang menurun atau terganggu, jumlah produksi asam organik yang melebihi jumlah ekskresinya. Pemasukan asam dari luar dan produksinya dalam tubuh lebih besar dibanding ekskresi total di ginjal. Kegagalan fungsi ginjal menyebabkan penurunan pembentukan amonia dan ion - ion hidrogen di dalam tubulus serta kehilangan natrium disertai retensi asam yang terikat (fosfat dan sulfat) dan asam organik oleh glomerulus. Pada asidosis metabolik kronik terjadi mekanisme penambahan buffer dari tulang (kalsium fosfat, kalsium karbonat) sehingga bikarbonat plasma relatif stabil. Akibat hilangnya penyimpanan buffer di tulang tersebut menyebabkan renal osteodystrophy(16). 
Analisis gas darah untuk menetapkan $\mathrm{pH}, \mathrm{pCO}_{2}, \mathrm{pO}_{2}, \mathrm{HCO}_{3^{-}}, \mathrm{CO}_{2}$ total, $\mathrm{BE}$ (base excess) dan saturasi oksigen $\left(\mathrm{SO}_{2}\right)$. Nilai normal pH: 7,36 - 7,44; $\mathrm{PCO}_{2}: 38$ - $42 \mathrm{mmHg} ; \mathrm{HCO}_{3}{ }^{-}$: 24 - $28 \mathrm{mmol} / \mathrm{L}$. Asidosis metabolik pada penyakit ginjal kronik ditandai oleh kadar bikarbonat plasma yang menurun, $\mathrm{pH}$ darah yang menurun dan peningkatan anion gap.

\section{PEMERIKSAAN FUNGSI TUBULUS}

Respons terhadap tes konsentrasi ini menurun pada kerusakan tubulus atau pada penyakit ginjal yang berat dengan penurunan laju filtrasi glomerulus(13). Tes ini tidak berlaku jika pasien mendapat terapi diuretika atau diet rendah protein.

\section{Tes konsentrasi urine}

Tes penyaring mengukur osmolalitas sampel urine 24 jam dengan aktifitas minimal. Jika osmolalitas $>800 \mathrm{mmol} / \mathrm{kg}$ atau berat jenis urine $>1,020$ maka aktifitas konsentrasi baik.

\section{Tes Vasopresin}

Pasien tidak boleh minum mulai pukul 18.00, kemudian pada pukul 20.005 unit vasopressin disuntikkan subkutan. Mengumpulkan sampel urine pasien hingga pukul 09.00 keesokan harinya. Cara lain, $2 \mu \mathrm{g}$ Desmopresin (DDAVP) intramuscular atau $40 \mu \mathrm{g}$ intranasal pada pukul 09.00 tanpa pembatasan cairan malam harinya, dan pengumpulan sampel urine hingga 12 jam berikutnya. Interpretasi hasilnya, pada berat jenis urine $>1,020$ atau osmolalitas $>700 \mathrm{mmol} / \mathrm{kg}$ (dicapai antara 5 dan 9 jam dalam tes DDAVP. Tes ini bisa dikombinasikan dengan pengukuran osmolalitas plasma, yaitu dengan rasio osmolalitas urine / plasma $=3$. Rasio osmolalitas urine / plasma $<2$ adalah abnormal.

\section{Tes Pemekatan urine}

Pemeriksaan ini tergantung atas respons hipofise posterior terhadap pemekatan air dan atas respons tubulus ginjal terhadap hormon antidiuretika. Tes ini digunakan dalam diagnosis banding polidipsi dan diabetes insipidus. Caranya, pasien tidak minum sehari sebelum tes setelah makan pagi sampai akhir tes dan tamping urine 24 jam. Respons ADH normal, jika osmolalitas $>900 \mathrm{ml} / \mathrm{I}$ dan berat jenis urine $>1,020$.

\section{Tes Pengasaman urine}

Pemeriksaan ini menilai kemampuan tubulus ginjal untuk membentuk urine asam dan mengekskresi ammonia. Tes ini berguna jika ada keragu - raguan apakah asidosis pada pasien diakibatkan oleh sebab pre renal atau kerusakan ginjal seperti asidosis tubulus ginjal. Metodenya, pasien puasa mulai tengah malam sampai akhir tes. Pasien mengumpulkan urine 24 jam. Pasien mendapat $0,1 \mathrm{~g}$ (1,9 mmol) ammonium klorida / $\mathrm{kg}$ berat badan dan minum satu liter air. Interpretasinya, normal urine diasamkan hingga $\mathrm{Ph} \leq 5,3$ dan akan mengandung $>1,5 \mathrm{mmol}$ amonia per jam (ammonia $<0,5 \mathrm{mmol} / \mathrm{jam}$, ada gangguan pada kemampuan pengasaman ginjal).

\section{Tes ekskresi zat warna untuk fungsi glomerulotubuler}

Pengukuran konsentrasi zat warna yang diekskresikan oleh ginjal dalam urine setelah suntika parenteral, bisa digunakan sebagai ukuran fungsi ginjal, sebagai contoh adalah zat warna Fenolsulfonftalein dan Indigo-karmin.

- Fenolsulfonftalein: zat warna merah fenol ini difiltrasi oleh glomerulus dan di sekresikan oleh tubulus proksimalis. Setelah suntikan intramuskuler atau intravena $6 \mathrm{mg}$, 40 - $60 \%$ akan diekskresikan dalam satu jam pertama dan 20-25\% dalam jam kedua. Jika kurang dari $50 \%$ diekskresi > 2 jam adalah abnormal.

- Indigo-karmin: Dengan sistoskopi kedua orifisium ureter diamati setelah suntikan intravena $100 \mathrm{mg}$ zat warna. Zat warna tampak keluar dari kedua ureter dalam konsentrasi sama selama 15 menit, ekskresi maksimal tercapai dalam 45 menit.

\section{PEMERIKSAAN URINE}

\section{PROTEINURIA}

Proteinuria digunakan sebagai petunjuk adanya penyakit ginjal. Proteinuria terjadi karena adanya peningkatan permeabilitas membran glomerulus (glomerular proteinuria), gangguan reabsorbsi tubulus (tubular proteinuria), peningkatan protein yang abnormal dalam plasma dan sekresi protein yang abnormal dalam traktus urinarius (post renal proteinuria). Proteinuria dapat terjadi secara fungsionil dan organik. Proteinuria fungsionil bersifat sementara pada beberapa 
keadaan sebagai akibat dari peningkatan aliran darah melalui glomerulus seperti aktifitas fisik yang berat, dehidrasi berat, intake protein meningkat, kedinginan, febris, kehamilan, ketegangan mental. Proteinuria organik dapat secara pre renal proteinuria (pre glomerular proteinuria), renal proteinuria (glomerular dan tubular proteinuria) dan post renal proteinuri karena kerusakan jaringan saluran kencing bagian bawah $(17,18)$.

Pemeriksaan protein urine dapat dilakukan secara kuantitatif, semikuantitatif dan kualitatif. Tes kuantitatif protein urine secara turbidimetri, metode biuret, metode Folin-Lowry, Esbach dengan urine tampung 24 jam dan carik celup menggunakan fotometer refleksi. Pemeriksaan semikuantitatif yakni tes rebus, tes sulfosalisilat dan carik celup visual. Pemeriksaan kualitatif dengan metode dipstick, Heller's nitric acid ring test, Robert ring test, Heat test dan Sulfosalicylic acid test.

\section{SEDIMEN URINE}

Sedimen urine adalah partikel di dalam urine yang dapat berasal dari darah, ginjal dan saluran kemih atau merupakan kontaminasi yang berasal dari luar saluran kemih. Pemeriksaan sedimen urine dikerjakan dengan metode manual dan hasilnya dilaporkan secara semikuantitatif atau dengan metode manual atau otomatik dan hasilnya dilaporkan secara kuantitatif. $(17,18)$

\section{Praanalitik}

Pada tahap ini diperhatikan penampungan urine, cara pengambilan dan waktu pemeriksaan. Sebaiknya digunakan urine pekat, segar, $\mathrm{pH}<7,5$ dan mencegah kontaminasi unsur diluar ginjal dan saluran kemih menggunakan porsi tengah. Untuk wanita, sebaiknya tidak sedang haid. Urine dimasukkan dalam penampung yang terbuat dari plastik, bermulut lebar, kering, bersih, bertutup rapat dan sekali pakai. Pemeriksaan dikerjakan dalam waktu tidak lebih dari 2 jam sejak urine dikumpulkan. Bila pemeriksaan ditunda, urine disimpan pada suhu $4^{\circ} \mathrm{C}$ selama 8 jam atau diberi pengawet asam borat $1 \mathrm{~g} / 100$ $\mathrm{mL}$ urine atau $1 \mathrm{~mL}$ formaldehida $16 \% / 100 \mathrm{~mL}$.

\section{Analitik}

Mengocok urine dalam tempat penampung dan tuang urine ke dalam tabung sentrifus plastik berujung kerucut dengan volume $12 \mathrm{~mL}$, kemudian disentrifus dengan kecepatan $450 \mathrm{~g}$ selama 5 menit bila menggunakan metode National Committee for Clinical Laboratory Standards (NCCLS) atau menggunakan $10 \mathrm{~mL}$ urine dengan kecepatan $500 \mathrm{~g}$ selama 5 menit metode Japanese Committee for Clinical Laboratory Standards (JCCLS).

Konversi kecepatan sentrifus dari g ke RPM dengan diketahui jari-jari $(r)$ sentrifus menggunakan normogram atau rumus:

$$
\begin{aligned}
& \mathrm{G}=118 \times 10^{-1} \times \mathrm{r} \times \mathrm{RPM} \\
& \mathrm{RPM}=1000 \times\left\{\begin{array}{c}
\mathrm{g} \\
-\cdots 11,18 \times \mathrm{r} \\
\end{array}\right\}
\end{aligned}
$$

- Setelah sentrifus selesai, lapisan supernatan dibuang dan ditinggalkan endapan $0,4 \mathrm{~mL}$ untuk metode NCCLS atau 0,2 mL untuk metode JCCLS.

- Satu tetes sedimen tersebut diletakkan diatas kaca obyek yang ditutup dengan kaca penutup $18 \times 18 \mathrm{~mm}$, selanjutnya dilihat dibawah mikroskop dengan pembesaran 10 $X 10$ (LPK) untuk unsur silinder atau $10 \times 40$ (LPB) untuk melihat unsur eritrosit, leukosit.

\section{Pasca analitik}

Pelaporan sedimen urine secara semikuantitatif. Pada penyakit ginjal kronik didapatkan bentukan silinder yang merupakan cetakan protein yang terjadi pada tubulus ginjal. Silinder terdiri dari protein TammHorsfall yang disekresi oleh tubulus distal dan bagian ascending Loop of Henle. Silinder lebih banyak terbentuk pada tubulus distal dan tubulus koligentes karena $\mathrm{pH}$ urine di daerah tersebut asam. Untuk terjadinya silinder diperlukan protein Tamm-Horsfall, albumin, pH urine yang asam, konsentrasi garam yang tinggi dalam filtrat glomerulus dan aliran urine yang lambat. Pada penyakit gagal ginjal seringkali didapatkan silinder seluler (silinder eritrosit, silinder leukosit dan silinder epitel), silinder berbutir (silinder granula / korel / cast), silinder lilin/waxy dan silinder lemak. 


\section{PENYAKIT GINJAL STADIUM AKHIR (SINDROMA UREMIA)}

Penyakit ginjal progresif dengan laju filtrasi glomerulus yang turun, kurang dari $10 \%$, gejala klinis uremia mulai terlihat. Gejala klinis berupa iritasi traktus gastrointestinalis karena perubahan urea ke amonia, gangguan mental dan neurologik (nyeri kepala, sedatif), perubahan hematologi dan perubahan vaskular, twitching, napas bau busuk atau bau amoniak. Berikut ini gejala sindroma urea $(1,2)$

1. Gangguan elektrolit dan asam basa darah

- Kalium : hiperkalemia

- Natrium : retensi natrium

- Kalsium : hipokalsemia

- Fosfat : hiperfosfatemia

- Magnesium : meningkat

- Aluminium : meningkat

- Asidosis metabolik

2. Kelainan kardiovaskular

- Mempercepat timbulnya aterosklerosis

- Hipertensi

- Perikarditis

- Gangguan fungsi myokardia

3. Kelainan hematologi

- Anemia

- Gangguan fungsi lekosit

- Perdarahan

4. Gangguan saluran cerna

- Anoreksia, mual, muntah, gastroparesis

- Perdarahan saluran pencernaan

- Gangguan indera pengecapan

5. Renal osteodystrophy

- Osteomalacia

- Osteitis fibrosa (hiperparatiroid sekunder)

- Osteosclerosis

- Osteoporosis

6. Kelainan neurologi

- Sistem syaraf pusat: sulit tidur, kelelahan, gejala psikologi

- Neuropati perifer

7. Miopati: terutama otot-otot proksimal

8. Gangguan toleransi karbohidrat: resistensi insulin di perifer, hipoglikemia

9. Gangguan endokrin dan metabolik

- Gangguan toleransi glukosa

- Gangguan fertilitas

- Hipotermi

10. Hiperurikemia

11. Pruritus, kalsifikasi jaringan lunak, bekuan uremia
Tahap akhir dari penyakit ginjal kronik adalah ESRD / End stage renal disease (GGT= gagal ginjal terminal), yang ditandai dengan penurunan laju filtrasi glomerulus hingga kurang dari 15\% dan adanya gejala uremia berupa iritasi traktus gastrointestinalis karena perubahan urea ke ammonia, gangguan mental dan neurologik, perubahan hematologi dan perubahan vascular, twitching, napas bau busuk atau bau amoniak. Pada tahap ini pasien memerlukan terapi pengganti seperti transplantasi ginjal atau dialisis.

\section{DAFTAR PUSTAKA}

1. Mc Phee SJ, Lingappa V, Ganong W, 2003. Pathophysiology of Disease An Introduction to Clinical Medicine. MC Graw-Hill Companies. $4^{\text {th }}$ ed. 444-469.

2. Price S, Wilson L, 2006. Pathophysiology Clinical Concepts of Disease Processes. EGC. $6^{\text {th }}$ ed. $865-1004$.

3. Akbari, Swedko, Clark, et al, 2004. Text at Archives of Internal Medicine. Arch Intern Med. Sep; 164 (16): 1788-92.

4. A National Clinical Guideline, 2008. Diagnosis and Management of Chronic Kidney Disease. 1 - 57. www.sign.ac.uk

5. John R, Webb M, Young A, 2004. Unreferred Chronic Kidney Disease. Am J Kidney Dis. 43 (5): 825 - 835.

6. Coresh. J, 2003. Prevalence of Chronic Kidney Disease and Decreased Kidney Function. Am J Kidney Dis. 41: 1 - 12.

7. Burtis C, Ashwood E, 2001. Fundamental of Clinical Chemistry. W.B. Saunders Company. $5^{\text {th }}$ ed. $699-715$.

8. Bishop M, Fody E, Schoeff L, 2005. Clinical Chemistry Principles. Lippincott Williams $\&$ Wilkins. $5^{\text {th }}$ Ed. $219-230$.

9. Wallach J, 2007. Interpretation of Diagnostic Tests. Lippincott Williams \& Wilkins. $8^{\text {th }}$ Ed. 816 - 818.

10. Schrier R, 2005. Manual of Nephrology. Lippincott William \& Wilkins A Wolter Kluwer Company. $6^{\text {th }}$ Ed. $117-186$.

11. Levey A.S, Coresh J, Balk E, et al, 2003. National Kidney Foundation Practice Guidelines for Chronic Kidney Disease. Ann Intern Med. 139: 137 - 147. 
ISSN 1978-2071 (Print); ISSN 2580-5967 (Online) Jurnal IImiah Kedokteran Wijaya Kusuma 6 (1) : 14-22

12. American Clinical Laboratory Association. 2007. info @ labresultsforlife. org Lab Tesrs Online, http:// Labtestsonline.org/ understanding/ conditions/kidney.

13. Baron D.N, 2002. Clinical Pathology Select. EGC. $4^{\text {th }}$ Ed.232 - 255.

14. Selvin E, Kottgen A, 2009. Kidney Function estimated from Cystatin C. Eur. Heart J.

15. Renal tubular Acidosis. 2007; 22: 906 910.

16. Fischbach F, Dunning M, 2004. A Manual of Laboratory and Diagnostic Test. Lippincott Williams and Wilkins. $8^{\text {th }}$. ed. $185-236$.

17. Ringsrud K, Linne JJ, 1995. Urinalysis and Body Fluids. Mosby Inc. 50 - 54. 